\title{
DID THE OTTOMAN PHYSICIANS MAKE ANY CONTRIBUTIONS TO THE MEDICAL SCIENCE IN THE OTTOMAN EMPIRE IN THE FOURTEENTH CENTURY
}

\author{
(At the Flourishing Period of the Empire)
}

\section{ESIN KAHYA}

Ottomans founded a government in 1299 , that is, 700 years ago in a small village in Sogut near nowadays İzmid (Nicosia) and the first scientific activities began to appear in the fourteenth century. However they did not need to do any fundamental studies in order to prepare the scientific background. For they had been already made in Islamic World, beginning from the eighth century. And the Seljukids appreciated and used the legacy of Islamic World. Following them the Ottomans who lived in Anatolia also used all the scientific works that were written in Islamic World and became authority in their field. For instance, one of them was Avicenna lived in eleventh century in Islam.

During the fourteenth century in the Ottoman Empire, medreses were founded at first as the institutions of education and naturally science. One of them was open in Nicosia and then Brussa. They did not carry only a curriculum focused on religious sciences, but also positive sciences that were called as rational sciences.

Among the health institutes founded in this period can be mentioned Yildirim Hospital in Brussa. It was founded as a part of Brussa Yildirim Complex City, which contained a mosque, a madrasa, a tomb, a hospital and a bath ${ }^{1}$.

The hospital served, not only an institute where was used for treatment but also as a medical school. Among its staff were found a chief-physician, some surgeons, physicians, an ophthalmologist, and a pharmacist. Among the staff of the hospital were found a cook, a laundryman. There are also some documents about them in the Archives ${ }^{2}$.

${ }^{1}$ Akbulut, Brussa with whole aspects (in Turkish), İstanbul 1937, 96-97.

${ }^{2}$ Ottoman Arhives, Cevdet, Sthhiye Defteri, no: 527 (dated 1742) and no 214 (dated 1797). 
Its first physician was Physician Husnu who studied medicine in Iran. Sheyhi (Yusuf Sinan al-Dîn) and Ibn Sherif (the writer of the famous medical work named Yadigar) also served in this hospital in fifteenth century.

Some documents that were found in Ottoman Archives give us certain detail about the hospital. Through them can be possible to learn about same physicians who served in this hospital; for instance two of them were Abdullah Efendi and Nuh Efendi of Girit who also served as a chief physician (1628-1707) in Ottoman Palace".

As a conclusion it can be said that this hospital kept continue to give service until 1854 beginning from 1399. It was made restorations in 1617 , 1649,1669 and 1671 .

During the fourteenth century the scientific activity was not only focused on Islamic science, but also there were scientists who were interested in positive science, even some of them mainly were interested in Islamic science but they also positive science and wrote on astronomy and mathematics, including in medicine. Fenari and Kadızade-i Rumi were scientists who were interested in positive sciences, especi ally mathematics and astronomy in the fourteenth century.

In medicine the Ottoman physicians kept Islamic tradition. They accepted the classical Greeks physicians, but also Ibn Sina, Rhazes as authority. But in their works they added their experience. In general they preferred wrote their works in Turkish and explained the reason why they wrote in Turkish as follows: 'I wrote my work in Turkish in order to let as many people as possible to understand and use it'. We can mention Hadji Pasha, Jamal al-Din Aksarayi, Hakim Barakat and Ishak b. Murad among the medical savants.

Ishak b. Murad was born in Gerede (near Nicosia), but we do not know the exact dates of his birth, except the century he lived. He studied medical plants and collected some of them for use in his treatment of certain diseases. He wrote a medical book, called Edviyet al-Mufrede (Simple Drugs) in 1390 that was accepted as a first medical work in the Ottoman Empire in the fourteenth century ${ }^{1}$.

\footnotetext{
${ }^{3}$ Ottoman Archives, Cevdet, Sihhiye Defteri, no 132 (dated 1696).

${ }^{1}$ See for some of its copies: Bursa Basna ve Yazma Library, Haraccioğlu 1134/1; Fatih, Millet Library, (tip) 109; Gotha Library, Pertsch. 113; İstanbul University Library (TV) 495; Malatya Library 1196/1; Bibliothéque National Man. Turc AF.170 (Paris), Süleymaniye, Pertevnihal 744/2, Zile Library 309; Topkapı Palace, Revan 1757.
} 
Ishak b. Murad prepared his work using the medical works of previous Muslim authorities. Among them are mentioned Ibrahim Seyyid Zeyneddin Ismail Curcani (d. 1135), Ibn Sina (980-1037). Al-jurcani was a famous physician who lived in the Seljukian period. He wrote a huge book, named Zahire-i Hwarezmshahi. This book was a medical work, including all subjects of medicine but it was mainly famous for its pharmaceutical section.

Ishak b. Murad was also influenced by Ibn Sina's medical knowledge, as were all other the Ottoman medical men. He used Ibn Sina's Canon and alCurcani's Zahire-i Hwarezmshahi (the Drugstore of Hwarezmshah) in particular".

Edviye-i Mufiede (Simple Drugs) consists of two chapters. There is an alphabetic list of drugs in the first part of the work. The writer did not only give the Turkish names of the drugs, but also added Persian and Arabic names.

Edviyet al-Mufiede also gave the usage of the drugs, including some prescriptions about headache, earache.

In this chapter Ishak b. Murad gave the characteristics of certain kinds of bread, such as bread made of barley and rice $e^{6}$. He also mentioned various plants like the stinging nettle, figs, quinces, common vetch, nutmegs, wheat, common fumitory, mulberry, coconut, date, marshmallow, cassias, cucumber, black pepper, cinnamon, fennel, garlic, onion, mastic, sumac etc. and gave their medical effects, and explained which parts could be used. For instance, certain plant oil, their seeds, roots or juice could be useful for treatment. For instance, he pointed out that 'wild radish cures jaundice? 7 .

In this chapter, Ishak b. Murad did not use only plants as medicament but some animals and animal products as well. One of them was fish. Ishak b. Huneyn says 'fish cures the snake poisoning. if a patient eats from the flesh of a cock, his paralysis is healed".

5 This work has several copies in the manuscript libraries of İstanbul. It was also published in İran (Zeyneddin Ebu İbrahim İsmail b. al-Hasan b. Muhammed b. Muhammed Ahmed al-Husni al-Curcani, Zahire-i Hwarezmshahi. Tahran $1301 \mathrm{H}$.)

${ }^{6}$ Ishak b. Huneyn, Edviyet al-Mufrede, Bursa, Haraccioğlu, 1134/1, p.4a. It was copied in 792 H. (1390).

${ }^{7}$ Ibid., p. 12a.

${ }^{8}$ Ibid., pp. 2b, 3a. 
Ishak b. Murad also said that the some animal fats could be useful, for example lion-fat, duck-fat etc. Could be mentioned among them. He mentioned the characteristics of yoghurt in the following words:

'Yoghurt is good for acidic stomachs; sweet yoghurt is better than the other qualities. And if it is eaten with garlic it will be more suitable for the stomach. It is also good if it is drunken with zencebil. It has a good influence if it is eaten after taking a bath." These examples are important from the standpoint of folk medicine.

The second chapter of his work is about medical treatment and contained the following four sections:

1. Diseases of the head (including in the brain diseases such as headache, paralysis, etc.)

2. Diseases of the chest (such as certain diseases of the thoracic cavity)

3. Diseases of the abdominal organs

4. Some diseases which can be treated by surgical treatment

In the first chapter some disturbances such as spleen ache, earache, bad breath, toothache, certain urinary diseases, including certain contagious diseases like leprosy are present in outlines ${ }^{10}$.

At the end of the second chapter there is another part on aphrodisiac drugs, named bahname by Ottoman physicians.

Edviyet al-Mufrede also contains a chapter named Istilahat-i Lugat in which he gives the Turkish equivalents of some Arabic words in the book.

Ishak b. Murad treated diseases depending on their symptoms; he counted the pulse of the patient. However, he mainly depended on classical Islamic medicine and its humoral theory which was presented by Hippocrates (460-377 B.C.) and Galen (AD.130-201) and, also certain authorities in the Islamic World like Ibn Sina. He examined his patients from the head to the foot and, diagnosed and treated them depending on the symptoms that he had identified. He also prepared,special preparations that were suitable for their complaints ${ }^{11}$.

9 Ibid., 31a.

10) Ibid., pp. 31a-33a.

11 A.D.Erdemir, Geredeli İshak b. Murad, Türk Dünyası, Tarih Dergisi, v.8, n.90, (1994), pp. 50-54. 
Another medical men mentioned here is Physician Barakat. We do not have much knowledge about his life, except that he lived in Aydin during the time of Mehmed Bey (1330-1340). He knew Arabic and Persian. He wrote a book named Tuhfe-i Mubarise that was also said one of the early medical works in Anatolia. it was written in Arabic and named Lube alNihaye and then translated into Persian, afterwards it was also translated into Turkish by the writer, himself.

Physician Barakat was highly influenced by Ibn Sina's famous medical work, Canon. In Tuhfe-i Mubarise there are a lot of quotations from that work. Barakat's work consists of 2 parts. In the first part certain natural facts are explained in 2 sections; the first section has 7 chapters on the humoral theory and the 3 natural powers which are responsible for the functions of digestion, thought, and sexual activity. The first four chapters of the second section deals with natural circumstances. The first chapter is explanation about colours; the second chapter is about fatness and thinness; the third chapter classifies and describes the four stapes of life, i.e., childhood, youth, maturity and old age.

The second part also has 4 sections; the first section consists of 6 chapters on certain fevers like malaria, swellings and some other diseases and their treatments. In addition, it also explains the symptoms of the diseases and ways of diagnosing them by the means of urine samples and through the humours.

The third section has 9 chapters in which we find information on public health and healthy living, varieties of food, the uses of swimming and some other activities including sleeping as well as insomnia. The fourth section has $\mathbf{8}$ chapters and they are about methods of treatment making of vomiting, bleeding, etc. and some simple and composite drugs.

As were mentioned above, some of the savants lived in the fourteenth century were interested in Islamic sciences and also medicine. One of the best examples of these scientists is Jamal al-Din Aksarayî. He lived during the reign of Murad I. Aksarayî was one of the important thinkers of this period. He completed his education in Amasia although he was born in Aksaray, he went to Amasia because it was one of the cultural centers of that time. $\mathrm{He}$ was educated near his fellow townsman citizen, Fahr al-Din Ilyas of Aksarayî. Later, he served as teacher and became chief military judge, after Pir Nizam al-Din Muhammed Curcani' s death. 
Although we do not know the exact date of those positions, we learn that he left the city when the governor of the city and his friend, Hadji Shadgeldi Pasha's position was in danger, and his friends and relatives life was in risk. Aksarayî came to Konia and was appointed as the judge of the city by Halil Beyzade of Karaman in 1382. Afterwards he returned to his birthplace, Aksaray, and became a teacher in Zincirli Madrasa.

Aksarayî gave his lectures at three different places. When he was going to the madrasa he gave lectures to the first group who were named peripatisian (mashaiyyun), and between the doors of the madrasa and classroom he gave lectures to another group of students and, he gave the lectures to the third group in the classroom. He continued lecturing until his death in 1388 (or 1399).

Jamal al-Din Aksarayî was interested in different subjects. Among them can be mentioned philosophy of religion and Islamic judiciary, and medicine. In Hadaik al-Shakaik Mecdi Efendi said that 'he was a wise, perfect scholar. A lot of people used his knowledge; many students whose number could not be determined surrounded his chair. He wrote a book on religion, named Kesshaf and, he also wrote a commentary on Mucez'.

Although Aksarayî was well known because of his works on Islamic sciences, his commentary on Mucez also had an important place in Ottoman medical studies.

Ibn Nafis' work Mucez was a very popular book among Ottoman physicians, and some physicians wrote commentaries on it. One of these commenteries belongs to Aksarayî ${ }^{12}$. Aksarayî's Commentary (Hall al-Mucez) has 4 chapters. At first, he gives the ideas of Ibn Nafis, and then his own ideas and opinions, as well as those of some other famous Islamic medical men, like Ibn Sina and Rhazes.

In the first chapter Aksarayi gives information on the humoral theory in all medical books in the Islamic World and after this general introduction he explains the functions of the sensory organs, such as the eye, and the ear. Here he mentions the 3 main powers that are responsible for all the functions of the human body.

\footnotetext{
${ }^{12}$ Some of its versions are in Süleymaniye Library, Laleli 1634, 1635; Șehit Ali Pasha 2056, 2059. Ayasofya 3666 .
} 
Aksarayî defined disease as 'loss of health for certain reasons' and classified diseases in several ways. One of them was their origins of diseases. Some of them occur because of their existence in mother or father; nowadays they are called hereditary diseases. Some other diseases occur during birth or pregnancy. All these diseases occur before the birth of the baby and they are natural diseases.

In addition to these diseases, there are some others that are caused by worms and some others by bad effects coming from the outside. These bad effects can enter the body through the vessels or skin. They show different symptoms in different organs; they can cause trouble in the skeleton or the muscles.

Jamal al-Din thought that all organs in the body could be affected in different ways except the heart; it is a noble organ. Nearly all of the Muslim physicians claimed that no diseases could occur in the hearth as Jamal al-Din claimed. Ibn Sina was one of them.

Jamal al-Din classified diseases as simple and complex diseases depending on their causes. If they occurred because of only one cause, they were simple diseases; but if they occurred because of more than one cause, they were complex diseases. For instance some diseases were caused by, not only winds, but also by some other outer effects.

He also classified diseases as those which appear individually, and these which appear with some other diseases.. He called the laler diseases 'companion diseases'.

Jamal al-Din thought that food and drink were also among the causes of diseases. For 'in order to be healthy, man needs good food and drink as well as an active and peaceful life. ${ }^{13} \mathrm{He}$ believed that a balanced diet meant good health.

Aksarayi offered certain diet, cupping and vomiting as the methods of therapy in some diseases. Diseases are caused by unhealthy humours and these humours spoilt the balance of the body. For they have to be thrown away from the body as soon as possible. Thus the body is freed from troublesome humours. He recommended some emetics, purgatives and lacsatives.

${ }^{13}$ Süleymaniye Library, Ayasofya 3666, 32b-35a. 
In the first chapter, Jamal al-Din also gives information on sleep and insomnia and some other natural functions with pulse and urine in order to diagnose the diseases. He says that pulse produced by the flexion and contraction of the arteries. He thought that the number of pulse beats changes, depending to the health of a person and his humours. It is normally 20, and becomes 30 in sickness. He also explains how a physician should a patient's take pulse and also gives a diagram showing pulse changes, which resembles to electrocardiogram.

William Harvey discovered the circulation of blood in 1628 . He described his experiment s on this matter in De Motu Cordis et Sanguinis. In his work he gave the number of pulse as 30 in a normal human being. Today we accept 76 as normal, although we know that it changes according to age, sex and some other conditions.

The second chapter of the work, Hall al-Mucez, was named 'Medical Practice'. In this chapter, after explaining the general principles of hygiene and warning people against some unbalanced humours and the diseases that they cause, he deals with simple and complex medicaments. Among them are found some purgatives and emetics. He also recommends fasting and cupping; they can be helpful to keep the humours in balance. In general the medicaments are plants, for example he mentions melilot (melilotus) and says that it is humid and balanced from the point of coldness and hotness. It is good for humid wounds and for pains, especially the pains in the eyes. It is cultivated in Iran and some other countries. It has round leaves. if it is used mixed with honey it is good as an analgesic. It is generally applied on the painful area ${ }^{14}$.

Nowadays we do not use it as a drug but we know that its effective agents are cumarin and hydrocumarin. It was frequently mentioned in Ottoman pharmacology.

Among the simple drugs are beans, anise, and some other well known vegetables and fruits or herbs that were also regularly used by Ottoman physicians in those days. He also mentioned some animal medicaments like milk and honey. 
The third chapter of the work describes some diseases that are known mainly as psychological or neurological diseases like melancholy, epilepsy, forgetfulness, etc. Some of them are actually not diseases, but only symptoms of certain diseases, like shivering and convulsion. He compares these two diseases (7) one another, and explains the cause of them. He thinks that shivering can occur only in the organs of motion and it indicates that there is something wrong in medulla spinals, but convulsion appears as a weakness of the body. Movements of the patients are not coordinated and the organs are motionless ${ }^{15}$.

He, later, deals with all the diseases of the body, beginning from the diseases of the head down to the feet. He also added a part about sexology.

In the fourth part Jamal al-Din wrote about the epidemic diseases. Malaria was mentioned among them. He classified it three parts and explained all of them in detail. Among them he mentioned leprosy, measles, itching and hydrophobia. He knew that when one was bitten by mad dog hydrophobia occurred. He also thought that it was not an ordinary contagious disease, but that it creates some neurological problems.

In this chapter he also dealt with some diseases which need surgical treatment. Among them are some skin diseases caused by insect bites, for example by ants, ticks, spider's etc.

As conclusion it can be said that Jamal al-Din Aksarayî had not only important studies for Islamic science, but also for medicine. His work mentioned above was very influential in his own time and afterwards.

In the fourteenth century in the Ottoman Empire some physicians were trained in Egypt, the place of the cradle of the culture, not only in Islam but also before Islamic period of time. After completed their training they returned their country and served as physician. They generally preferred to write their works in Arabic, although the physicians who trained in Anatolia wrote their works in Turkish as were mentioned above. One of the physicians of the physicians was trained in Egypt is Jalal al-Dîn Hizir b. Al alHattab known as Hadji Pasha. First, he studied Islamic sciences in Cami alEzher in Cairo. Mubarehshah Maliki and Sheyh Muhammed b. Mahmud Ekmel al-Din were among his teachers. Molla Fenari was also educated in the

\footnotetext{
${ }^{15}$ Ibid.,153b.
} 
same place with him. Hadji Pasha then studied medicine in Kalavun Hospital in Cairo. Afterwards he returned his country in 1380 and then came to Aydin on the invitation of Isa Bey of Aydinoglu (1348-1391). He worked as judge in Ayasulug and Birgi.

As a physician he was also very famous and wrote several books which were used as handbooks in the Ottoman Empire for many years. He wrote his books in Arabic and Turkish.

Some of his medical works were Kitab al-Talim, Shifa al-Askam ve Deva al-Alam, al-Kummi al-Jalali, Muntehab-i Shifa, Teshil al-Shifali. Muntehab-i Shifa was written in Arabic in 1370. Hadji Pasha prepared his book using old, classical works in Islam, and in some parts of them, he commented on them, including the works of Hippocrates, Ibn Sina and Galen. In his introduction to this work he gave some advice to medical men.

In this work, Hadji Pasha classified diseases depending to their locations in the body and he described them beginning from the head down to the feet. Among the head diseases he mentioned the ear, nose, mouth and eye diseases too. Some of the symptoms of the diseases were given as separate diseases as the headache or the ear ache etc.

Hadji Pasha also explained some contagious diseases in this work, including malaria and itching. He prepared a summarised version of this work under the name of Kitab al-Ferid ${ }^{17}$.

Shifa al-Eskam ve Deva al-Alam was also written in Arabic in 1381. It contains four chapters and an article on medical ethics ${ }^{18}$. In the first chapter he gives general information about medicine. In the second, he deals with food, sherbets and simple and composite drugs; the third chapter is about the diseases of the whole body; the last chapter is about contagious diseases like tuberculosis, leprosy, measles, smallpox etc. In this chapter we also find information on certain forms of surgical treatment like fractures, dislocations and pus.

Hadji Pasha summarized Shifa al-Eskam and, called it Kitab al-Saadet ve al-Ikbal that was known as al-Kummi al-Celali"' This work also consists of four

\footnotetext{
l"i Regard Süleymaniye Library, Turhan Sultan 258.

17 One of its version is in the Süleymaniye Library, Yeni Cami, 258.

${ }^{18}$ Regard for its copy: Topkapı Palace. Ahmed III Library, 2070.

${ }^{19}$ A copy of this book is in Bayezid Library, Yeliyuddin Ef., 2536.
} 
chapters. The first chapter is about public health and the second chapter describes some kinds of food, sherbets and drugs; the third chapter describes the diseases of the whole body from the head down to the feet and the fourth chapter explains contagious diseases and some surgical problems.

Shifa al-Eskam was written in Arabic. However the writer, himself translated it into Turkish under the name of Muntehab-i Shifa ${ }^{20}$ Muntehab-i Shifa was used as a handbook in the Ottoman Empire more extensively. For this reason more copies of it exist in Turkish libraries than any other work written by Hadji Pasha ${ }^{21}$.

It contains 62 brief chapters. The first 8 chapters are about the head and its organs, diseases like headache, earache etc. and their drugs. Chapters $9,10,11,12,14,15$ contain the descriptions of the throat and the chest organs and diseases, including heart diseases. Chapters 13, 17, 18, 19, $20,21,22,25$ are about the digestive system. There is information about jaundice and certain bowel parasites, like worms, in the intestines. Chapters $23,24,28$ contain knowledge on the urinary diseases and their drugs; 26 is about gynecological diseases and their drugs; chapters 28, 54 are on pediatric diseases and their drugs. Chapters 29, 30, 31, 32, 33, 50 give knowledge about the arms and feet disorders and their treatment including problems of their muscles.

In the rest of the work the writer gives description of the contagious diseases (like leprosy), skin diseases and some surgical problems like fractures and certain types of wounds, and various complaints as obesity, losing hairs and baldness. Chapters 56-62 he explain various kinds of medicaments.

In Muntehab-i Shifa, Hadji Pasha prescribed tiryak-i faruk to the patients for scabies; eating fish and fennel were also recommended for scabies. Fennel should be cooked and then applied to the bitten place.

Hadji Pasha prescribed vinegar and rose oil in gargle form for toothache. He used snake flesh for lumbago and harmal seeds and roasted with rose oil for diarrhoea.

${ }^{20}$ Some of its version are in Süleymaniye Library, Hamidiye 1041/1 and Fatih, Millet, Ali Emiri, tip 123.

21 Zafer Önler, Celaleddin Hızır Pasha, Muntehab-i Shifa, Ankara 1991. 
He also prepared a summary of Muhtehab-i Shifa, ealled Teshil al-Shifa that consisted of 3 chapters; he gave brief information on theoretical medicine in its first chapter; he wrote about drugs in the second chapter. He dealt with the diseases of the body and their treatment in the third chapter ${ }^{22}$.

Apart from these works, Hadji Pasha wrote an article on hemorrhoids named Bevasir and a small book called Ihtilacname in which he described some diseases of the limbs.

As a conclusion, we can say that in the Ottoman Empire in the fourteenth century eminent physicians made valuable studies and gave stimulus for the studies in the following centuries. Their works were not only used in their times, but also in the following centuries. Especially Hadji Pasha was very effective on the following studies. Although they followed the traditional medicine, they also gave their medical experiences, their ideas and commentaries about the former medical studies and they also rejected earlier ideas time to time. 169.

${ }^{22}$ Süleymaniye Library, Kadizade Mehmed Ef. 341; Bibliotheque Nationale, Man. Turc AF. 